\section{LOVE METAPHORS IN MODERN THAI SONGS}

\section{Pattra Ngamjitwongsakul $^{1}$}

\begin{abstract}
This paper examines the love metaphors used by contemporary Thai songwriters in their modern Thai songs. The theoretical framework for the study is the theory of conceptual metaphor (Lakoff, 1987, 1993; Lakoff and Johnson, 1980; Lakoff and Turner, 1989). The data, approximately 3,615 songs from Grammy Entertainment Company, were collected from books, tapes, and the internet and were compiled from 1983 to 2000. Only 502 metaphorical expressions describing love were found.
\end{abstract}

This research revealed that the songwriters intend to convey far more than the surface meaning of their words. The theory of conceptual metaphor helps to explain the correspondences between a source domain and a target domain (love). Love metaphors allow us to comprehend love in terms of more clearly delineated concepts. In this study, twenty-two concepts were found which the songwriters use to conceptualize "love". I also found that the abstract concept of "love" can generally be understood in terms of image schema. This is where "love" is described with reference to physical objects and spatial relations. The conceptual metaphors reflect a schema of love as CONTAINER, PART-WHOLE, SOURCE-PATHGOAL, and LINK.

\footnotetext{
${ }^{1}$ Graduate student at Mahidol University.
}

\section{Introduction}

In everyday life, metaphors form an important component of our communicative repertoire. Metaphors structure our understanding of one thing in terms of another. Metaphors are found not only in everyday language but also in poetry and modern Thai songs, especially songs whose main theme is "love". Love is an important emotion which we can easily share with songwriters and has many shades of meaning. Love is not clearly defined in our experience and may be inconceivable without the use of metaphors (Lakoff and Johnson, 1980: 85). It is not surprising that songwriters express their feelings and emotions about "love" through metaphors. The metaphor may be the occasion for our experience of love, but it is also an essential tool for creating a comprehensive rhetorical and poetic language. According to Prasit Karpklon in Language and Thought (2532: 145), metaphors can stimulate the imagination and create emotions in our minds more effectively than ordinary language.

Metaphor is so widely used that we hardly notice it. Lakoff and Turner (1989) have explained metaphor in our everyday language as follows:

Metaphor is a tool so ordinary that we use it unconsciously and automatically, with so little effort that we hardly notice it . . . metaphor suffuses our thoughts, no matter what we are thinking about. It is accessible to everyone: as children, we automatically, as a matter of course, acquire a mastery of everyday metaphor. It is conventional: metaphor is an integral part of our ordinary everyday thought and language. (xi) 
Love Metaphors in Modern Thai Songs

Metaphor permeates our thought and speech, as a medium by which we make sense of our experiences and of our relationship with our surroundings. It seems that metaphors "have become so much a part of everyday use" (Ong and Govindasamy-Ong, 1996: 21) that the reasons metaphors are so pervasive are because they allow users to express all they want in a very few words and to display their talent or virtuosity with words (Green, 1989: 122). Moreover, users choose to use to employ indirectness (i.e., metaphor), because they are otherwise unable to express certain concepts (e.g., emotions) which are beyond their understanding or are inexpressible (Thomas, 1995: 122). Consider, for example, the metaphor "Love is fire." Fire produces heat, which makes us warm but sometimes burns us. Similarly, love can make us both happy and sad. As another example, with the expression "I was magnetically drawn to her" (Lakoff and Johnson, 1980: 49), the speaker expresses his or her emotion in terms of a physical force. One domain can easily be understood by reference to another domain which is more familiar to our understanding.

Lakoff and Johnson (1980) point out that "Since metaphorical expressions in our language are tied to metaphorical concepts in a systematic way, we can use expressions to study the nature of metaphorical concepts and to gain an understanding of the metaphorical nature of our activities" (7). The metaphorical concept LOVE IS A JOURNEY is reflected in a wide variety of expressions:

\section{LOVE IS A JOURNEY}

Look how far we've come.

We're at a crossroads.

We'll just have to go our separate

ways.

We can't turn back now.

I don't think this relationship is going anywhere.

Where are we?

We're stuck.

It's been a long, bumpy road.

This relationship is a dead-end street.

We're just spinning our wheels.

Our marriage is on the rocks.

We've gotten off the track.

This relationship is foundering.

(Lakoff and Johnson, 1980: 44-45)

In the examples above, love is structured by the concept of a journey. These everyday English expressions are used for reasoning about love. The metaphor can be understood as a mapping exercise from a source domain (in this case, JOURNEYS) to a target domain (in this case, LOVE). Entities in the domain of LOVE correspond systematically to entities in the domain of a JOURNEY (Lakoff, 1993: 207, 208). The lovers are travellers on a journey together, with their common life goals seen as destinations to be reached. The relationship is their vehicle, and it allows them to pursue common goals together. The relationship is seen as fulfilling its purpose only if it allows them to make progress toward their common goals. The journey is not easy because there are impediments or crossroads where decisions have to be made about which direction to go in and whether to keep travelling together. These JOURNEY metaphors do not all fit a single consistent image because of the various types of journey involved: a car trip, a train trip, or a sea voyage. Lakoff and Johnson (1980: 45) assert that such metaphors are, 
nevertheless, coherent because they are all JOURNEY metaphors.

As in contemporary English, the metaphorical concept of "love" appears in modern Thai songs. As mentioned above, metaphors penetrate our thoughts and language. Songwriters use metaphors to ensure that the audience understands the concept of "love" expressed in their songs. We can analyze the concepts of love according to the theory of conceptual metaphor developed by Lakoff (1987, 1993), Lakoff and Johnson (1980) and Lakoff and Turner (1989) on the basis of such metaphorical expressions for love that appear in modern Thai songs. Here are some examples of the conceptual metaphors in songs.

Example 1:

รักเป็นเช่นใด อยากได้เรียนได้ลอง ฉันจึงเชื่อใจให้เธอ เป็นคนสอนฉัน ทุกวันฉันเรียนอ่านหัวใจของเธอ ฉันจึง ได้เจอกับบทเรียนทรมาน

"What is love? I want to learn so I can trust you to teach me. Every day I learn to read your heart, but I find it only a painful lesson."

Example 2:

นี่หรือคือการตอบแทนของคนที่รักและไว้ใจ น่าขอบใจที่ เธอให้บทเรียนนี้

"Is this a reward from one whom I love and trust? Thank you for giving me the lesson."

These are examples of metaphors used by songwriters conceptualize "love" in terms of a lesson. The conceptual metaphor LOVE AS A LESSON is a common one used by contemporary Thai songwriters. The songwriters imply that the failure of a love relationship is a valuable experience that we should remember in the same way that we memorize our lessons. We can learn from our mistakes.

Conceptual metaphors for "love" are so pervasive in modern Thai songs that we may fail to notice them. There has never been a study which thoroughly examines metaphors in modern Thai songs from a cognitive point of view. I expect this study to provide valuable insight into the correspondence between the domain of love experience and other domains of experience. The research will also contribute to our understanding of how the metaphorical concept of "love" is expressed from Thai songwriters' perspectives. Finally, this study will be beneficial to further cognitive semantics.

\section{The theory of conceptual metaphor}

The metaphor has traditionally been viewed as a device of literary or rhetorical work - a matter of poetic language. However, Lakoff and Johnson (1980: 3) found that metaphor is not just a matter of language but extends to thought and reason. They explain that our conceptual system plays an important role in defining our everyday realities. Our conceptual system is largely metaphorical; therefore, the way we perceive the world should likewise be structured by metaphors. For example, the abstract concept "love" is treated as a journey in the English language, LOVE IS A JOURNEY, as mentioned previously in the introduction. That is, the concept "love" is metaphorically understood in terms of another concept, "a journey". Metaphor is not used in the literal sense but expresses a similarity between a source domain and a target domain. The LOVE AS JOURNEY mapping is a set of correspondences 
between the love relationship and various types of journey. The conceptual metaphor LOVE IS A JOURNEY is one way that English people conceive "love" in their culture. In different cultures, people may view "love" differently; so their conceptual metaphors may also vary.

\section{Ontological and epistemic correspondences}

Lakoff (1987: 386) states that conceptual metaphor consists of a set of correspondences between a source domain and a target domain. The correspondences can be divided into two types: ontological and epistemic. Ontological correspondences are those made between the entities in the source domain and the corresponding entities in the target domain. For example, in the LOVE IS A JOURNEY metaphor, the journey in the source domain corresponds to the love relationship in the target domain. Lakoff (1993: 207) characterizes a set of ontological correspondences between the JOURNEY domain and the LOVE domain. Glucksberg and McGlone (1999: 1545) illustrate this as in figure 1 .

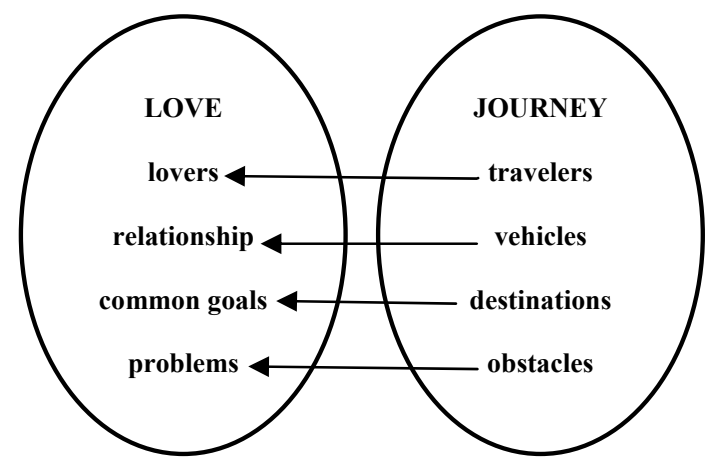

Figure 1: Hypothetical mappings between the domains of love and journeys

Epistemic correspondences consist of correspondences between knowledge about the source domain and knowledge about the target domain. Lakoff (1993: 208) describes the epistemic correspondences between the JOURNEY domain and the LOVE domain as the follows:

Source domain: Two travellers are in a vehicle, travelling toward common destinations.

Target domain: Two lovers are in a love relationship, pursuing common life goals.

Source domain: The vehicle encounters some impediment and gets stuck.

Target domain: The relationship encounters some difficulty, which makes it disfunctional.

Source domain: If the travelers do nothing, they will not reach their destinations.

Target domain: If the two lovers do nothing, they will not be able to achieve their life goals.

The human conceptual system includes an inventory of the structure of our knowledge of journeys and our ability to map from that structured knowledge to a conception of love. The structure of our knowledge of journeys can be seen as having welldifferentiated components such as travelers, a starting point, a path, impediments, destinations, vehicles, companions, and so on. Lakoff and Turner (1989: 61) call the structured knowledge in such a skeletal form "a conceptual schema". They have also employed the term "slots" for elements of a schema that are to be filled in. For example, a TRAVELLER is a slot in a JOURNEY schema. The metaphor LOVE IS A JOURNEY is a mapping of the structure of the JOURNEY schema onto the domain of LOVE in such a way as to set up the appropriate correspondences between 
TRAVELLERS and LOVERS, between STARTING POINT and INITIATION OF THE RELATIONSHIP, and so on.

Lakoff and Turner (1989: 65) continue by noting conceptual schemas establish our knowledge. They constitute cognitive models that we use in comprehending our experience and in explaining it. Cognitive models are acquired by our own direct experience and through our culture. They are used unconsciously and automatically. We can not observe them directly. Lakoff and Turner (1989: 66) insist that the cognitive models can be described on the basis of metaphorical mappings.

\section{Identifying the ontological and epistemic correspondences in modern Thai songs}

Both ontological and epistemic correspondences are revealed in modern Thai songs. I will begin by presenting correspondences forming the LOVE AS TRANSPORTATION metaphor. The songwriters map knowledge about transportation onto knowledge about love. There are three kinds of transportation that songwriters use in making metaphors: LOVE IS A CAR, LOVE IS A TRAIN and LOVE IS A SHIP. Although the three metaphors form no single image, they are coherent with each other since they are all TRANSPORTATION metaphors (see figure 2).

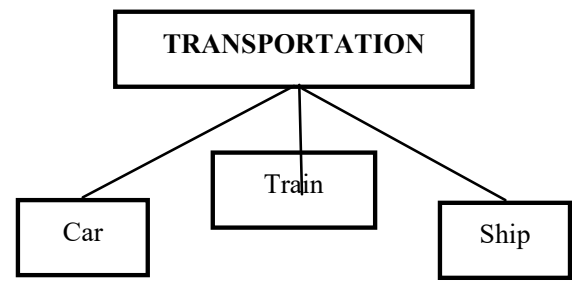

Figure 2: LOVE AS TRANSPORTATION
The LOVE AS TRANSPORTATION metaphor can be individually illustrated as follows.

\section{The LOVE AS CAR mapping}

I found five metaphors in which songwriters conceptualize love as a car. This metaphorical concept is utilized in four Thai songs.

Example 3:

เกิดมาแล้วไม่เสียชาติเกิด ที่ยังมีเธอข้างกาย ขาดเธอแล้ว จะหาอะไหล่ก็คงไม่มี

"I don't regret being born in this world because you stand beside me. You are a spare which I couldn't find if you were absent."

Example 4:

รอเวลามารักกัน เดี๋ยวนานๆ จะหมดไฟ รักเหมือนเป็น รถด่วน ต้องเร็วนะ จอดไว้ก็เท่านั้น ดูๆ ไปถ้าใจนั้น ตรงกัน ไม่ต้องเลยรีบออกไป

"Hurry up and come to love each other before our enthusiasm is exhausted. Love is like an express car. It is useless if it is dead. If our hearts are the same, we'd better develop our relationship."

\section{Example 5:}

ก่อนจะยอมให้เรื่องเราจบ ต้องทบทวนนิดนึงเกี่ยวกับใจ ผู้หญิงคนหนึ่งที่ยับและเยินจนพัง อยากให้เธอลองนึกดีๆ กับสิ่งที่เธอทำเฉย อย่าได้ชนแล้วหนีไปเลย $\ldots$. . เธอต้อง ชดใช้มาตามราคา

"Before ending our relationship, you should think about a woman's heart. It has shattered into pieces. I would like you to consider all the things you do. Don't be negligent! Don't run away after hitting my 
heart ... You must compensate for the cost of repairs."

Example 6:

ใจใคร โดนชนเรามีคนซ่อมแซมกันได้

"If one's heart is hit, we will have a mechanic repair it."

In examples (3), (4), (5), and (6), the ontological correspondences between the source domain CAR and the target domain LOVE are as follows:

Two lovers correspond to spare parts.

The love relationship corresponds to a car.

The common goals correspond to destinations.

The problems correspond to a car accident.

In the example (3), the epistemic correspondence for the metaphorical expression อะไหล่ 'spare' is as follow:

Source domain: A car consists of spare parts so the car can run.

Target domain: The love relationship can only be built if two lovers are involved.

In example (4), the epistemic correspondence for the metaphorical expression รักเหมือนเป็นรถด่วน "love is an express car' is as follows:

Source domain: An express car cannot delay.

Target domain: Love cannot wait.
In examples (5) and (6), the epistemic correspondence is as follows:

Source domain: When the car accident occurs, it does a lot of damage to the car.

Target domain: When the love relationship ends, it causes emotional damage to the lovers.

The metaphorical expressions ชน 'hit' and ใจ ใครโดนชน 'one's heart is hit' can be diagramed below.

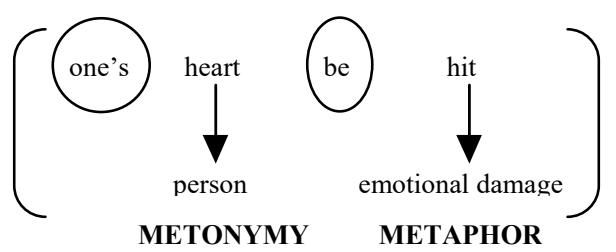

The expression หัวใจ 'heart' stands for a person. The expression ชน 'hit' is metaphorically understood as emotional damage. The metaphorical expressions ชน 'hit' and ใจใครโดนชน 'one's heart is hit' refer to the sadness caused by love.

In example (6), the epistemic correspondence is as follows:

Source domain: A car can be repaired.

Target domain: A lover's sick heart gradually heals as time passes.

The metaphorical expression ซ่อมแซม 'repair' can be diagramed this way: 


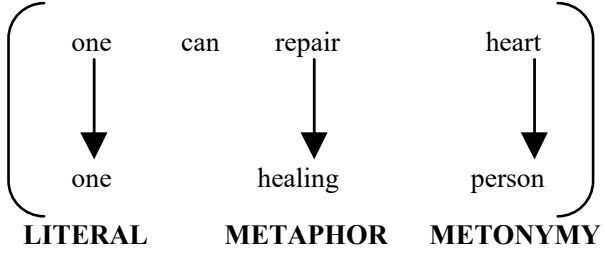

The expression ซ่อมแซม 'repair' is metaphorically described as being healed. The expression หัวใจ 'heart' stands for a person. The metaphorical expression ใจใคร โดนชน เรามีคนซ่อมแซมกันได้ 'if one's heart is hit, we will have a mechanic repair it' refers to a broken heart which will gradually heal as time passes.

\section{The LOVE AS TRAIN mapping}

I found three metaphors in which songwriters conceptualize love as a train. This metaphorical concept is reflected in the following passage from a modern Thai song.

Example 7:

มีใครต่อใครว่าเธอจะเปลี่ยนไป เราดันไม่ฟังอะไรเลย ใครๆ ก็เตือนว่าเธอจะสับราง เรายังไม่ฟังมันตามเคย . . . ชัดมั๊ยว่าเธอกำลังสับราง ทำไม ทำไม ทำไม ทำไม เขา เตือนเท่าไร ก็ยังไม่ฟัง ไม่เคยระวงระวัง ไม่เคยระแวง ไว้ใจทุกอย่าง ใครเตือนไม่ฟังเลยถูกหลอก

"Everybody told me that you would betray me. I ignored the warning. Everybody warned me that you would shunt the train onto another track. I didn't believe it as usual ... Is it clear that you are changing tracks? I will miss the train. Why didn't I believe the warning? I doubted the warning and also trusted you, but you deceived me."

In example (7), the ontological correspondences between the source domain TRAIN and the target domain LOVE are as follows:

Two lovers correspond to a train driver and a passenger.

The love relationship corresponds to a train.

The common goals correspond to a destination.

The epistemic correspondences are as follows:

Source domain: A train runs to its destination.

Target domain: Two lovers are involved in the relationship and pursue common life goals.

Source domain: The train driver shunts a train so a passenger will miss it.

Target domain: One of the lovers betrays another, so they will not reach a common destination.

The metaphorical expression สับราง 'shunt a train' is diagramed below.

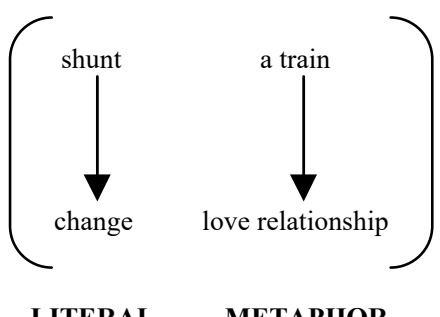

The expression สับ 'shunt' denotes "change". The expression ราง 'train' metaphorically describes the love relationship. The metaphorical expression สับราง 'shunt a train' refers to infidelity betrayal. 
Source domain: The passengers miss the train.

Target domain: One of the lovers knows of the other's betrayal; the relationship cannot continue.

The metaphorical expression ตกราง 'miss a train' is diagramed below.

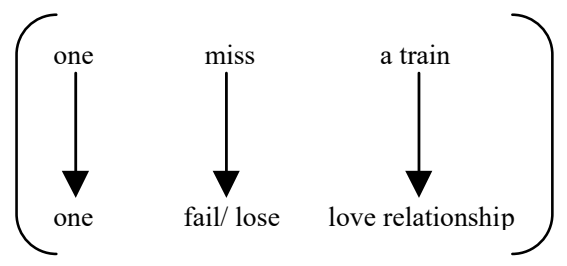

LITERAL LITERAL METAPHOR

The expression ตก 'miss' denotes "fail" or "lose" and the expression ราง 'train' metaphorically describes the love relationship. The metaphorical expression ตกราง 'miss a train' refers to a discontinued relationship.

\section{The LOVE AS SHIP mapping}

There is a metaphor in which the songwriter conceptualizes love as a shipwreck. This metaphorical concept is reflected in the following Thai song:

\section{Example 8:}

เหมือนตะวันจากฟ้า เหมือนนกลาจากรัง เหมือนเรือล่ม ใกล้ฝ่งง รักมาพังทลาย เหมือนมาถึงทางแยก เหมือนรอย ร้าวเริ่มแตก เหมือนชีวิตเริ่มแหลกแตกเป็นสองทางต่างกัน คงเหมือนฉันและเธอมาพบเจอ รักกันแต่เพียงไม่นานวัน รักถึงวันร้างราไม่มีทางกลับคืน

"We meet and love each other. Not so long, love is gone, and it cannot be revived. Similarly, the sun sets from the sky. The birds leave their nest. The boat sinks near the bank. Love is destroyed, and we are now at a crossroad. The rift between us grows and widens. Our lives are split into two ways."

In example (8), the ontological correspondences are:

The lovers correspond to ship.

The common goals correspond to bank.

The epistemic correspondence is:

Source domain: The ship sank before it arrived at its destination.

Target domain: Two lovers cannot continue their love relationship towards their common life goals such as a united family.

The metaphorical expression เหมือนเรือล่มใกล้ ฝั่ง 'the ship sinks near the bank' can be illustrated this way:

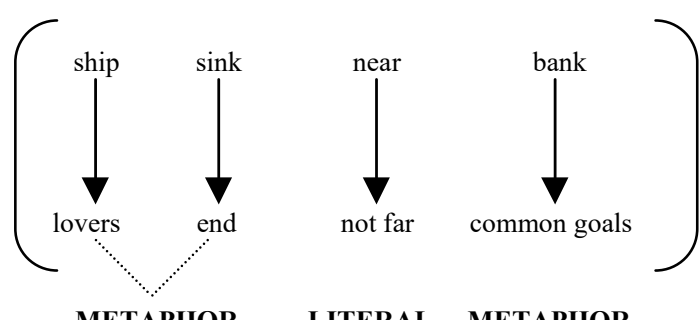

The expression เรือ 'ship' metaphorically describes the two lovers. The expression ล่ม 'sink' metaphorically means "end" while the expression ฝั่ง 'bank' is metaphorically understood as a common goal. The metaphorical expression เหมือนเรือ ล่มใกลัฝั่ง 'the ship sinks near the bank' refers to the ending of a relationship close to reaching a common goal. 
Love relationships have a starting point and endpoint; similarly, vehicles (cars, trains and ships) leave one point, then proceed towards their destinations. As this relationship is easily understood, love can be metaphorically viewed as vehicles travelling along a path.

Metaphor is actually based on our physical experience and our relationship with the external world. It is an intermediary between our conceptual representation of the world and our sensory experience of the world. Metaphor is also organized in conceptual systems. This organization of a conceptual system forms a cognitive map of one domain of experience to another domain, so that one domain can be understood through another domain which is somehow more basic or concrete. In other words, a more abstract domain is explained in terms of conventional mental images (Lakoff and Turner, 1989: 91), as in the above examples where concepts of "love" are related to concepts of "journey." Lakoff and Turner (1989: 94) state that the source domain may be mapped onto the target domain in order to create an image in the target domain. Thus, metaphor is used for explaining an abstraction.

\section{The notion of metaphorical concept, LOVE}

Lakoff and Johnson (1980: 3) explained that the human conceptual system which plays a central role in defining everyday realities, is metaphorical. It is reflected in linguistic expressions. The way English speakers perceive "love" can be structured by metaphors.

Moreover, Lakoff and Johnson say,

The concept of LOVE has a core that is minimally structured by the subcategorization LOVE IS AN EMOTION and by links to other emotions, e.g., liking. This is typical of emotional concepts, which are not clearly delineated in our experience in any direct fashion and therefore must be comprehended primarily indirectly, via metaphor (1980: 85).

Metaphors or metaphorical concepts as defined by Lakoff and Johnson allow us to comprehend the concept of "love" using terms of a more clearly delineated concept. Lakoff and Johnson (1980: 84) also identify the generalization of metaphors as follows:

Metaphor should deal with two different kinds of activities. For example, with LOVE IS A JOURNEY, love involves emotions, but a journey involves travelling.

Metaphor partially structures our everyday concepts. "Love" is partially structured in terms of "a journey". Only selected elements of the concept are used to correspond to.

Metaphor involves understanding one domain of experience. Here, "love" is expressed in terms of a very different domain of experience. It is based on human experience which determines properties and similarities between the source and target domains. Lakoff and Johnson assert that "a concept is structured by more than one metaphor" (1980: 86). Lakoff and Turner (1989: 89) add that various metaphors are related by commonplace knowledge that links their source and target domains.

Metaphors do not form a single image, although they are coherent with one another by virtue of being subcategories of a major category and therefore sharing a major common entailment (Lakoff and Johnson, 1980: 44). For instance, in the LOVE IS A 
JOURNEY metaphor, English speakers use different means of travel (vehicles) to explain a love relationship. These metaphors are not consistent; however, they are coherent with each other because they are all JOURNEY metaphors. A love relationship corresponds to various vehicles in the LOVE IS A JOURNEY mapping. "Vehicles" are a superordinate category that includes such basic level categories as "car, "train" and "boat". Lakoff (1993: 212) explains that mappings are at the superordinate rather than the basic level. The basic level is the level of rich mental images and rich knowledge structure. A mapping at the superordinate level maximizes the possibilities for mapping rich conceptual structures in the source domain onto the target domain.

In the present case, love metaphors likewise allow us to comprehend love in terms of more clearly delineated concepts. In the modern Thai songs I examined, I found 502 metaphorical expressions used to describe love, which were structured by a number of very different domains of experience. In all, twenty-two different concepts were used to conceptualize love. While the limited space does not permit the presentation of the individual analyses, the concepts themselves are given in figure 3 along with representative examples.

Figure 3: The metaphorical concept of love found in modern Thai songs

\begin{tabular}{|l|l|}
\hline Concepts & \multicolumn{1}{|c|}{ Expressions } \\
\hline 1. Road & $\begin{array}{l}\text { อีกหน่อยซึ่งคงไม่นาน ถึงวันนั้นแล้ว } \\
\text { เธอจะเข้าใจที่ฉันต้องบอกเธอให้จาก } \\
\text { กันไปเจ็บที่ใจเธอนั้น เมื่อเราต้องต้อง }\end{array}$ \\
\hline
\end{tabular}

\begin{tabular}{|c|c|}
\hline & $\begin{array}{l}\text { แยกทางมันก็คงไม่ต่างจากใจฉัน } \\
\text { "One day you will } \\
\text { understand the reason } \\
\text { why I have told you to } \\
\text { part from me. I feel as } \\
\text { much pain as you feel } \\
\text { when we have to go our } \\
\text { separate ways." }\end{array}$ \\
\hline 2. Games & $\begin{array}{l}\text { หมากเกมนี้ฉันก็รู้ว่าจะต้องลงเอย } \\
\text { อย่างไร ไม่ต้องรอให้จบเกม ฉันก็ } \\
\text { พร้อมจะยอมตัดใจ } \\
\text { "I know how the game of } \\
\text { chess will end. You will } \\
\text { not have to wait until the } \\
\text { game ends. I am ready to } \\
\text { part from you." }\end{array}$ \\
\hline 3. Person & $\begin{array}{l}\text { เมื่อใดความรักเดินชนไม่ยอมหลีก ก็ } \\
\text { คงได้ลุ้นกันอีกสักครั้ง ... รักมัน } \\
\text { เดินลุยผ่านตรงเข้ากลางหัวใจ รักมัน } \\
\text { ยังคลืบคลานและรุกรานเรื่อยไป } \\
\text { "Whenever love walks } \\
\text { towards us and doesn't } \\
\text { step aside, it causes great } \\
\text { excitement . . . Love } \\
\text { walks straight to our } \\
\text { heart. It gradually creeps } \\
\text { towards us." }\end{array}$ \\
\hline $\begin{array}{l}\text { 4. Natural } \\
\text { Elements } \\
\text { (Sun) }\end{array}$ & $\begin{array}{l}\text { บอกหน่อยทำไม ฝนจึงหลั่งไหล } \\
\text { คล้ายดังน้ำตา เจ็บปวดสิ่งใด บอก } \\
\text { หน่อยเถิดหนา ลมพัดพาน้ำตาฟ้ามา } \\
\text { จากไหน หรือแสงตะวันได้พลันจาก } \\
\text { ลา ฟ้าจึงมืดไป เหมือนรักจากไกล } \\
\text { แล้วไม่กลับคืน ฉันยืนเดียวดาย } \\
\text { "Why is the rainfall like } \\
\text { tears? Please tell me what } \\
\text { hurts it. Where does the } \\
\text { wind blow tears of sky? } \\
\text { Since the sun sets and the } \\
\text { sky gets dark, similarly, } \\
\text { love leaves me far and } \\
\text { doesn't return. I therefore } \\
\text { stand alone here." }\end{array}$ \\
\hline
\end{tabular}




\begin{tabular}{|c|c|}
\hline 5. Education & $\begin{array}{l}\text { รักเป็นเช่นใด อยากได้เรียนได้ลอง } \\
\text { ฉันจึงเชื่อใจให้เธอเป็นคนสอนฉัน } \\
\text { ทุกวันฉันเรียนอ่านหัวใจของเธอ ฉัน } \\
\text { จึงได้เจอกับบทเรียนทรมาน } \\
\text { "What is love? I want to } \\
\text { learn it, so I trust you will } \\
\text { teach me. Everyday I } \\
\text { learn to read your heart, } \\
\text { but I find only a painful } \\
\text { lesson." }\end{array}$ \\
\hline 6. Seasoning & $\begin{array}{l}\text { อยากมีความรักวันนี้ให้นานเท่านาน } \\
\text { ความรักจะหวานต้องเกิดเพราะไว้ใจ } \\
\text { "Today I need love to last } \\
\text { as long as it can. Because } \\
\text { of trust, love is sweet." }\end{array}$ \\
\hline $\begin{array}{l}\text { 7. Furnishings } \\
\text { (Kitchen } \\
\text { Utensil) }\end{array}$ & $\begin{array}{l}\text { บาดแผลของความรักนั้นโหดร้าย ฉีก } \\
\text { ไว้ที่ใจฉันอยู่นานแสนนานเพียงใด } \\
\text { "The wound from love has } \\
\text { badly scarred my heart for } \\
\text { a long time." }\end{array}$ \\
\hline $\begin{array}{l}\text { 8. Natural } \\
\text { Occurrences } \\
\text { (Rain) }\end{array}$ & $\begin{array}{l}\text { เข้าใจว่าความรักเหมือนลมเรง ต้อง } \\
\text { ปล่อยให้มันไป ไม่อาจกักขัง ไม่อาจ } \\
\text { เก็บไว้ รู้เรอไม่เหมือนเก่า เมื่อสายลม } \\
\text { ต้องไป เมื่อรักมันต้องลาต้องให้ไป } \\
\text { "I know that love is like a } \\
\text { strong wind. I have to let it } \\
\text { blow. It couldn't be } \\
\text { restrained. I know that you } \\
\text { have changed. Like a wind, } \\
\text { love leaves me. I let it go." }\end{array}$ \\
\hline $\begin{array}{l}\text { 9. Plants } \\
\text { (Flower) }\end{array}$ & $\begin{array}{l}\text { เก็บกอดดวงใจที่เธอทำลาย นี่ใจฉัน } \\
\text { กร่อนหัวใจอ่อนๆร้ารอนมื่อรักโรยร } \\
\text { "I hug my heart which you } \\
\text { destroyed. It is weak and } \\
\text { painful after love has } \\
\text { withered." }\end{array}$ \\
\hline 10. Dream & $\begin{array}{l}\text { อดทนไว้ แค่หนามมันตำมันแทงใจ } \\
\text { แค่ฝันที่เลวร้าย อดทนไว้ แค่ฟ้ามัว } \\
\text { มันมืดมน แค่คนที่เคยรักเขาจากไป } \\
\text { "Be patient! When my } \\
\text { darling parts from me, it }\end{array}$ \\
\hline
\end{tabular}

\begin{tabular}{|c|c|}
\hline & $\begin{array}{l}\text { is just a nightmare, a } \\
\text { cloudy sky, or a thorn } \\
\text { piercing my heart." }\end{array}$ \\
\hline 11. Business & $\begin{array}{l}\text { ตอกบัตรเข้าไปรักเช้าที เย็นอีกที } \\
\text { ฝึกหัดกับรักตั้งเป็นปี ไม่สนใจตอก } \\
\text { บัตรก็ตรงเป๊ะ ทุ่มเทไปเท่าไร . . . } \\
\text { ถ้าไม่มอง ถ้าไม่แคร์ ให้เธอโยนซอง } \\
\text { ขาวมาเลย } \\
\text { "I punctually clock in and } \\
\text { clock out every morning } \\
\text { and evening. I have } \\
\text { practiced making love to } \\
\text { you for many years. You } \\
\text { are not interested in me.. } \\
\text {. If you don't care for me, } \\
\text { you should hand over the } \\
\text { white envelope." }\end{array}$ \\
\hline 12. Drama & $\begin{array}{l}\text { จบแล้วละคร จากนี้คือตอนที่เราสอง } \\
\text { ต้องเดินแยกทาง . . . รักนี้ไม่มีทาง } \\
\text { เป็นจริง } \\
\text { "A drama is ended. From } \\
\text { now on both of us go our } \\
\text { separate ways . . . Love } \\
\text { couldn't come true." }\end{array}$ \\
\hline $\begin{array}{l}13 . \\
\text { Transportation } \\
\text { (Car) }\end{array}$ & $\begin{array}{l}\text { ใจใคร โดนชนเรามีคนซ่อมเซมกันได้ } \\
\text { "If one's heart is hit, we } \\
\text { will have a mechanic } \\
\text { repair it." }\end{array}$ \\
\hline 14. Health & $\begin{array}{l}\text { อกหักกะทันหัน . . . มันเจ็บอก มัน } \\
\text { ปวดใจ แทบเดินไม่เป็น เพราะโดน } \\
\text { เธอเล่นทีเผลอ เสียหายเสียหาย ถึงไม่ } \\
\text { ตายก็โคม่า } \\
\text { "I am immediately broken } \\
\text { hearted ... I have a pain in } \\
\text { my heart. I can hardly } \\
\text { walk because you leave } \\
\text { me. I haven't died yet but } \\
\text { I am in a coma." }\end{array}$ \\
\hline $\begin{array}{l}\text { 15. Terrain } \\
\text { Features } \\
\text { (Sea) }\end{array}$ & $\begin{array}{l}\text { รักเธอมั่นคงแน่นอน ดุจดังท้องทะเล } \\
\text { ที่ยังงดงาม } \\
\text { "Like the beauty of the sea, } \\
\text { I consistently love you." }\end{array}$ \\
\hline
\end{tabular}




\begin{tabular}{|c|c|}
\hline 16. War & $\begin{array}{l}\text { ให้เราลืมสงครามและอยากให้ถาม } \\
\text { ตัวเองดูสักที ถ้ารักกันจริงจัง อยาก } \\
\text { ให้รักเราดูดี อย่ามัวทำอย่างนี้ต่อกัน } \\
\text { "We'd better forget the } \\
\text { war between us. We } \\
\text { should ask ourselves } \\
\text { once. If we still love each } \\
\text { other and want our love } \\
\text { relationship to last, we } \\
\text { shouldn't fight against } \\
\text { each other." }\end{array}$ \\
\hline 17. Legality & $\begin{array}{l}\text { ก็เห็นมาตำตา หลักฐานก็มัดตัวทุก } \\
\text { อย่างว่าเธอจะเหินห่าง ก็เห็นไป } \\
\text { ควงใครเมื่อวาน . . . บอกเอาไว้ } \\
\text { ให้ รีบมามอบตัว อย่าให้ฉันโกรธ } \\
\text { มากไป ก็บอกดีๆ เธอก็คงเข้าใจ } \\
\text { ยังไงก็คนรักกัน } \\
\text { "Yesterday I saw you } \\
\text { strolling arm in arm with } \\
\text { a woman. This evidence } \\
\text { is enough to prove that } \\
\text { you are estranged from } \\
\text { me . . . You should } \\
\text { immediately surrender } \\
\text { yourself to me. Don't } \\
\text { make me be very angry. } \\
\text { You may understand } \\
\text { what I have warned you. } \\
\text { We are still lovers." }\end{array}$ \\
\hline 18. Food & $\begin{array}{l}\text { ฉันโอบกอดเธอด้วยรักและความ } \\
\text { เข้าใจ ฉันป้อนความรักให้เธอมีใจ } \\
\text { แเ็็แกร่ง } \\
\text { "I hug you with great } \\
\text { affection. I feed love to } \\
\text { you so that your heart is } \\
\text { strong." }\end{array}$ \\
\hline 19. Beverage & $\begin{array}{l}\text { รู้แล้วครั้งนี้ รักคือตัวการทำคนเบิก } \\
\text { บานให้กลายเป็นเศร้า ขืนรักแล้ว } \\
\text { หลงให้มันมอมเมา ก็โดนมันแผดเผา } \\
\text { เจียนตาย }\end{array}$ \\
\hline
\end{tabular}

\begin{tabular}{|c|c|}
\hline & $\begin{array}{l}\text { "I have already realized } \\
\text { that love changes a } \\
\text { cheerful person to a sad } \\
\text { person. If I go on to let } \\
\text { myself be intoxicated } \\
\text { with love, it will burn me } \\
\text { until I die." }\end{array}$ \\
\hline 20. Trick & $\begin{array}{l}\text { เปลี่ยนแปลง เรื่องมันแดงว่าใจเธอ } \\
\text { เปลี่ยนไปจากเรา เมื่อเธอเจอเขานั้น } \\
\text { ยืนข้างเธอ . . .รักของเราเปลี่ยนไป } \\
\text { เปลี่ยนแปลงราวกับเล่นกล } \\
\text { "Your secret is revealed. } \\
\text { Your heart betrays me. } \\
\text { Now a new person stays } \\
\text { beside you . . . Our love } \\
\text { relationship changes like } \\
\text { a trick." }\end{array}$ \\
\hline 21. Light & $\begin{array}{l}\text { และถึงแม้จะเหนื่อยจะท้อจะก้าวไป } \\
\text { อาจหกล้มสักนิดไม่เป็นไรเพราะว่า } \\
\text { รักสว่างอยู่ตรงกลางหัวใจ แค่เพียง } \\
\text { เขาอยู่ในดวงใจฉัน } \\
\text { "I am so tired and } \\
\text { disappointed but I keep } \\
\text { stepping. Sometimes, I } \\
\text { fall down. It doesn't } \\
\text { matter since love is bright } \\
\text { in my heart. My darling is } \\
\text { the only one in my heart." }\end{array}$ \\
\hline 22. Bond & $\begin{array}{l}\text { ลืมตาหลับตา ต่อไปนี้จะมีแต่เธอ } \\
\text { อยากเอารักไปมัดเธอไว้ไม่ให้หนี } \\
\text { "I either open or close } \\
\text { my eyes. I love only } \\
\text { you. Love ties you to me } \\
\text { so you cannot escape } \\
\text { from me." }\end{array}$ \\
\hline
\end{tabular}

These categories include mapping rich conceptual structures in the source domain onto the target domain. I find that these basic levels of categorization already give a clear image of love and that to put these categorizations into its superordination will lessen such images. Other metaphors are 
miscellaneous; they are not grouped into any concepts as each has only one expression found in modern Thai songs. Also, they do not fit together by being subcategories of a major category and sharing a major common entailment.

In conclusion, concepts of love cannot be expressed precisely but are best understood indirectly via metaphors. They are used for explaining the concept "love" in terms of a familiar experience or concrete example. The conceptual system plays an important role in forming a cognitive map of one domain of experience to another domain. The conceptual system varies from culture to culture (Lakoff and Johnson, 1980: 146). Therefore, people who have cultural differences are likely to view the concept of love differently. We are normally aware of a reflection of this conceptualization in the way language is used. The analysis of the concept "love" in English expressions presented by Lakoff and Johnson (1980) can equally be applied to expressions in modern Thai songs. The researcher found many Thai expressions used to structure our understanding of love in terms of different concepts. These metaphors are imaginative and creative, and they are capable of giving us a new understanding of the concept of love. Since Thai songwriters can certainly be classified as a group of Thai language users, we can understand the metaphorical concepts which songwriters use in conceptualizing love within a Thai cultural framework.

\section{Image schemas}

Johnson (qtd. In Lakoff, 1987: 271) claims that basic experience is structured in a skeletal and schematic image. Johnson (1987) calls this an "image schema". All experiences are obviously understood in image schemas. As an example, in English people say, "You wake out of a deep sleep and peer out from beneath the covers into your room" (qtd. in Lakoff, 1987: 271). This is an example of the embodiment of a CONTAINER schema - a schema consisting of a boundary distinguishing an interior from an exterior. In this study, the researcher also finds the conceptual structure of "love" that which can be reflected in image schema. This is where "love" is understood in terms of physical objects and spatial relations. How we understand the abstract concept of "love" in terms of CONTAINER, PART-WHOLE, SOURCE-PATH-GOAL and LINK schemas will be explained in detail below.

\section{The CONTAINER schema}

In modern Thai songs, songwriters describe the abstract concept of "love" as an emotion that unites two lovers. "Love" is also related to other emotions. People can perceive love and love-related emotions with their heart. Heart is an organ of the person's body. It is a center of the person's thoughts and emotions, especially love. According to Johnson (1987), parts of our bodies can be viewed as containers for something. Just as we can use an open container to put something in. Love is, therefore, viewed as something found in a container such as a heart or a box. For example:

Example 9:

เธอเติมความรักไว้ให้ฉันรู้สึก และยังซึมลึกข้างในหัวใจ เมื่ออยากจะพบเธอเพียงเฝ้ามองออกไปยังฟ้าไกล

"You present your love to me. It is absorbed into my heart. When I want to meet you, I only look at the sky."

Heart is a place where lovers gather all their good and impressionable feelings. 
Heart is viewed as a container, while love is understood in terms of a physical object.

\section{The PART-WHOLE schema}

While we consider our bodies as a whole with parts, we are also aware of the partwhole structure of other objects. Heart is an important organ of the person's body, and it is also as a container for emotions. In modern Thai songs, songwriters usually use heart to stand for two lovers. For instance:

Example 10:

รักคืออะไร รักคืออะไร อยากเข้าใจ อยากรู้กักแล้วเป็นไง อยากค้นดู จะดีร้ายเพียงใด อาจจะเป็นไฟร้อนแรงเข้ามา คอยเผาใจ อาจจะเป็นสายน้ำเย็นเข้ามาชโลมใจ

"What is love? I want to know love. I will discover whether it is good or not. It may be a fire that burns our heart. Otherwise, it will be a cool stream that bathes our heart."

Heart stands for two lovers. Fire and water are metaphorically understood as love. This metaphorical expression refers to the fact that love can bring sadness and happiness to a couple.

\section{The SOURCE-PATH-GOAL schema}

When lovers start to build their love relationship, they continue their relationship through various stages. The stages of a love relationship can be presented using the SOURCE-PATH-GOAL schema. A love relationship consists of initial stage (source), a sequence of intermediate stages (path), and a final stage (goal). Two lovers start their relationship with the dream of achieving common life goals. They have to face problems in their love relationship.
Songwriters describe the stages of a love relationship as a road, a game, a drama, business, education, transportation, and plants. All these concepts reflect the beginning and ending of the love relationship and the passage of time since the two lovers began their relationship. They spend time in learning and understanding each other. The songwriters compare this long period of time to the time required for the formation of a canal, the growth of plants, and vaporization. The schema can be diagramed in this way:

L 1

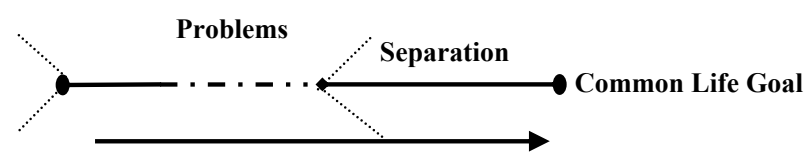

L 2

Temporal Dimension

\section{Figure 4: Love relationship}

Two lovers build their love relationship and then try to achieve their common life goals. Ultimately they will have to face problems in their love relationship. There are three alternatives for the couple. First, the two lovers can solve the problems between them and continue on their path to achieving common life goals. Second, the two lovers can remain in a disfunctional relationship and give up achieving common life goals. Last, if they are unable to move through the difficulties, they may abandon their relationship without achieving their common life goals. Each of them would look for another person to build a love relationship with and form new life goals.

\section{The LINK schema}

The umbilical cord is the first link connecting infants to their biological mothers. Similarly, love joins two people in 
a love relationship. It forms a link or a bond between the two. In modern Thai songs, many metaphors describe the lovers' bond in terms of a law, contract or profit (economical bond), game rule or stake, social bond such as exists between students and teacher, rope, straw, ring, and chain. Therefore, love can be viewed using the LINK schema. For example:

Example 11:

ความรักนั้นคล้ายๆ กีฬา ทุกทุกคนก็มามาเล่นกีฬาของ หัวใจ หมดเวลาจะไปไหน ถ้าหากจิตใจคนเล่นยังมี ก็ต่อ เวลาอีกทีซิ ต่อมันไปอีกที ไม่มีใครว่า . . . ต่อเวลาอีกที ซิ ต่อกันไปอีกที ก็คงดีกว่า แต่กติกายังเดิมนะ

"Love is like a sport. Everybody comes to play a sport of the heart. When the time is up, where will they go? If the players need to play, please lengthen time. Nobody reproaches it . . . lengthen the time, please. It is very good to lengthen time, and the rules should be as the old ones."

The intensity of love is understood as the attachment between the lovers. The two lovers maintain their relationship with in an established pattern; similarly, the players on a team must play the game according to fixed rules so that they can play harmoniously. Therefore, the contract or rules in the game are metaphorically understood as representing the lovers' bond.

\section{Conclusion}

In conclusion, I found 502 metaphors used by Thai songwriters to describe love. Love metaphors allow us to comprehend love in terms of a more clearly delineated concept. The analysis of metaphors in modern Thai songs reveals that metaphorical concepts of love are usually constructed in a coherent and systematic way. The songwriters use only twenty-two concepts to conceptualize "love". These conceptual metaphors reflect the schemas of CONTAINER, PART-WHOLE, SOURCE-PATH-GOAL, and LINK. In this study, I rely on my personal knowledge and experience in analyzing metaphors and interpreting them on the basis of their context. The ability to interpret metaphors depends on individual differences in cognitive and linguistic process.

\section{References}

Glucksberg, Sam, and Matthew S. McGlone. 1999. When love is not a journey: What metaphors mean. Journal of Pragmatics 31: 1541-1558.

Green, Georgia M. 1989. Pragmatics and natural language understanding. New Jersey City: Lawrence Erlbaum Associates.

Lakoff, George. 1987. Women, fire and dangerous things: What categories reveal about the mind. Chicago: University of Chicago Press.

Lakoff, George. 1993. The contemporary theory of metaphor. In Andrew Ortony (ed.), Metaphor and thought ( $2^{\text {nd }}$ ed). 207-208, 212. Cambridge: Cambridge University Press.

Lakoff, George, and Mark Johnson. 1980. Metaphors we live by. Chicago: University of Chicago Press.

Lakoff, George, and Mark Turner. 1989. More than cool reason: A field guide to poetic metaphor. Chicago: University of Chicago Press. 
Ong Siow Heng and Nirmala GovindasamyOng. 1996. Metaphor \& public communication. Singapore: Graham Brash (Pte).

Prasit Karpklon. 1980. Language and thought. Bangkok: Ramkhamhaeng Printing Press.

Thomas, Jenny. 1995. Meaning in interaction: An introduction to pragmatics. London: Longman. 